\title{
KOMPETENSI DAN KOMUNIKASI ORGANISASI TERHADAP KINERJA PEGAWAI YANG DIMEDIASI OLEH MOTIVASI KERJA (STUDI PADA DINAS PENANAMAN MODAL DAN PERIZINAN TERPADU SATU PINTU (DPM-PTSP) PROVINSI JAMBI)
}

\author{
Muhammad Arif ${ }^{1}$, Sigit Indrawijaya ${ }^{2)}$ \\ ${ }^{1)}$ PNS Pada DPM-PTSP Provinsi Jambi \\ 2,Prodi Magister Manajemen FEB Universitas Jambi \\ Corresponding author: moharif0106@gmail.com
}

\begin{abstract}
Abstrak
Penelitian ini bertujuan untuk menganalisis pengaruh kompetensi dan komunikasi organisasi terhadap motivasi kerja dan kinerja pegawai, serta untuk menganalisis motivasi kerja terhadap kinerja pegawai. Populasi dalam penelitian ini adalah pegawai pada DPM-PTSP Provinsi Jambi yang berjumlah 147 orang. Ukuran atau jumlah sampel dalam penelitian ini ditentukan berdasarkan teori yang dikembangkan oleh Slovin dengan nilai $e=5 \%$ sehingga diperoleh sampel sebanyak 107 orang. Pendekatan dalam penelitian ini menggunakan pendekatan kuantitatif dengan metode survey dan menggunakan analisis data Partial Least Square (PLS). Hasil penelitian menunjukkan bahwa kompetensi dan komunikasi organisasi memiliki pengaruh terhadap kinerja pegawai, baik secara langsung maupun tidak langsung melalui motivasi kerja. Hal ini menjelaskan bahwasanya jika DPM-PTSP Provinsi Jambi memiliki pegawai dengan kompetensi yang baik, serta didukung dengan adanya komunikasi organisasi yang berlansung secara efektif, maka hal ini akan meningkatkan motivasi pegawai dalam bekerja. Jika pegawai telah memiliki motivasi yang tinggi dalam bekerja, maka hal ini secara tidak langsung akan memberikan dampak pada hasil hasil kerja pegawai yang optimal.
\end{abstract}

Kata Kunci: Kompetensi, Komunikasi Organisasi, Motivasi Kerja, dan Kinerja.

\begin{abstract}
This study aims to analyze the influence of competence and organizational communication on work motivation and employee performance, and to analyze work motivation on employee performance. in this study were 147 employees at DPM-PTSP Jambi Province. The size or number of samples in this study was determined based on the theory developed by Slovin with a value of $e=5 \%$ in order to obtain a sample of 107 people. The approach in this study uses a quantitative approach with survey methods and uses Partial Least Square (PLS) data analysis. The results showed that organizational competence and communication had an influence on employee performance, either directly or indirectly through work motivation. This explains that if DPM-PTSP Jambi Province has employees with good competence, and is supported by effective organizational communication, then this will increase employee motivation to work. If employees have high motivation to work, then this will indirectly have an impact on optimal employee work results.
\end{abstract}

Keywords: Competence, Organizational Communication, Work Motivation, and Performance.

\section{PENDAHULUAN}

Dinas Penanaman Modal dan Perizinan Terpadu Satu Pintu (DPM-PTSP) merupakan lembaga teknis daerah yang mempunyai tugas pokok dan fungsi sesuai dengan 
Peraturan Daerah Nomor 5 Tahun 2013 yaitu melaksanakan penyusunan dan pelaksanaan kebijakan daerah bidang penanaman modal dan pelayanan perizinan terpadu. Dinas ini terbentuk pada dasarnya dalam rangka mempercepat dan mempermudah pelayanan pemberian dokumen perizinan dan nonperizinan kepada masyarakat. Penyelenggaraan sistem pelayanan terpadu dilaksanakan di lingkungan kementrian/lembaga, pemerintah provinsi, pemerintah kabupaten/kota, dan/atau kecamatan.

Sebagai lembaga teknis daerah yang mempunyai tugas pelayanan perizinan, DPMPTSP harus memiliki sumber daya yang baik. Sumber daya manusia merupakan modal dasar pembangunan nasional. Maka, kualitas Sumber Daya Manusia (SDM) senantiasa harus dikembangkan dan diarahkan agar bisa mencapai tujuan yang diharapkan. Berbicara mengenai sumber daya manusia sebenarnya dapat dilihat dari 2 (dua) aspek, yaitu aspek kuantitas dan kualitas. Aspek kuantitas mencakup jumlah SDM yang tersedia, sedangkan aspek kualitas mencakup kemampuan SDM baik fisik maupun non fisik, kecerdasan dan mental dalam melaksanakan pembangunan sehingga dalam proses pembangunan pengembangan SDM diperlukan, sebab kuantitas SDM yang besar tanpa didukung kualitas yang baik akan menjadi beban pembangunan suatu bangsa.

Untuk mendukung tercapainya tujuan organisasi tersebut, DPM-PTSP tentu harus mampu melaksanakan pekerjaannya dengan baik sehingga menghasilkan output yang maksimal sesuai dengan harapan instansi. Untuk itu instansi harus menyadari bahwa untuk menghasilkan output yang maksimal maka diperlukan pegawai yang produktif, karena tingginya kinerja pegawai akan memberikan hasil kinerja organisasi yang tinggi pula, sebaliknya rendahnya kinerja pegawai akan menyebabkan rendahnya kinerja organisasi.

Kinerja merupakan ukuran dari keberhasilan pelaksanaan pekerjaan dari setiap orang baik secara individu maupun sebagai anggota kelompok suatu organisasi atau instansi pemerintah. Kinerja pegawai memiliki peranan penting bagi organisasi, apabila kinerja yang ditampilkan rendah maka akan mengakibatkan instansi dalam mencapai tujuan menjadi terhambat. Kinerja merupakan hasil kerja secara kualitas dan kuantitas yang dicapai oleh seorang pegawai dalam melaksanakan tugasnya sesuai dengan tanggung jawab yang diberikan kepadanya. Setiap organisasi baik swasta maupun organisasi pemerintahan berusaha untuk selalu meningkatkan kinerja pegawainya demi tercapai tujuan yang telah ditetapkan suatu organisasi tersebut.

Pada manajemen kinerja kompetensi lebih berperan pada dimensi perilaku individu dalam menyesuaikan suatu pekerjaan dengan baik. Kompetensi kinerja dapat diartikan sebagai perilaku-perilaku yang ditunjukkan dari pegawai yang memiliki kinerja yang sempurna, konsisten dan efektif dibandingkan dengan karyawan yang memiliki kinerja rata-rata. Untuk dapat mencapai hasil kerja yang optimal tentunya pegawai harus memiliki kompetensi yang baik, sesuai dengan kemampuan dan pengetahuannya, hal ini dikarenakan pegawai yang berkompeten dalam suatu bidang akan lebih mempermudah pegawai tersebut untuk berkinerja lebih baik (Yuliana, 2017).

Seorang pegawai yang memiliki kompetensi yang tinggi seperti pengetahuan, ketrampilan, kemampuan, dan sikap yang sesuai dengan jabatan yang diembannya selalu terdorong untuk bekerja secara efektif, efesien dan produktif. Hal ini terjadi karena dengan kompetensi yang dimiliki pegawai bersangkutan semakin mampu untuk melaksanakan tugas-tugas yang dibebankan kepadanya (Rande, D., 2016). Pentingnya kompetensi pegawai adalah untuk mengetahui cara berpikir sebab-akibat yang kritis, memahami prinsip pengukuran yang baik, memastikan hubungan sebab akibat (causal) dan mengomunikasikan hasil kinerja strategis sumber daya manusia pada atasan (Dessler, 2009). 
Disamping dengan dituntutnya untuk memiliki kompetensi pegawai yang baik, suatu organisasi juga harus memperhatikan komunikasi yang berlangsung dalam suatu organisasi. Hal ini dikemukakan oleh Golddhaber dalam Alam, S (2014) yang mengatakan bahwa komunikasi merupakan proses penciptaan dan saling menukar pesan dalam satu jaringan hubungan yang saling bergantung satu sama lain untuk mengatasi lingkungan yang tidak pasti atau yang selalu berubah-ubah. Komunikasi sangat esensial sekali bagi kehidupan organisasi khususnya untuk pegawai dan atasan dalam mencapai tujuan. Penggunaan komunikasi yang baik akan mengurangi ketidakpastian dan memperbaiki kinerja pegawai.

Komunikasi dalam suatu organisasi merupakan hal utama yang tidak kalah pentingnya dalam mencapai tujuan organisasi. Hubungan komunikasi yang baik antara atasan dengan bawahan, dan antara bawahan dengan sesama bawahan dalam suatu organisasi sangat berpengaruh besar dalam menjembatani terciptanya peningkatan produktivitas kerja karyawan di dalam organisasi tersebut. Pace dan Faules (2013) yang menyatakan bahwa alasan lain yang mendukung pentingnya komunikasi organisasi adalah karena dengan adanya komunikasi organisasi yang kondusif, nyaman dan positif, maka dipercaya akan meningkatkan kepuasan kerja dari para anggota organisasi termasuk didalamnya adalah pegawai.

Disamping dengan dituntutnya ada komunikasi yang efektif dalam organisasi sebagai upaya meningkatkan kinerja pegawainya, adapun faktor lainnya yang tidak kalah penting dalam mempengaruhi kinerja pegawai adalah motivasi kerja. Menurut McClelland mengatakan bahwa "Motivasi merupakan Kondisi jiwa yang mendorong seseorang dalam mencapai prestasinya secara maksimal. Pentingnya motivasi karena motivasi merupakan hal yang menyebabkan, menyalurkan dan mendukung perilaku manusia. Supaya mau bekerja giat dan antusias mencapai hasil yang memuaskan, motivasi semakin penting karena atasan membagikan pekerjaan kepada bawahannya untuk dikerjakan dengan baik dan teritegrasi kepada tujuan yang diinginkan (Mangkunegara, 2014).

Motivasi merupakan dorongan terhadap serangkaian proses perilaku manusia pada pencapaian tujuan. Menurut Jerald Greenberg dan Robert A. Baron dalam Wibowo motivasi merupakan serangkaian proses yang membangkitkan (arouse), mengarahkan (direct), dan menjaga (maintain) perilaku manusia menuju pada pencapaian tujuan. Membangkitkan berkaitan dengan dorongan atau energi di belakang tindakan. Motivasi juga berkepentingan dengan pilihan yang dilakukan orang dan arah perilaku mereka. Sedang perilaku menjaga atau memelihara berapa lama orang akan terus berusaha untuk mencapai tujuan (Wibowo, 2014).

Bertitik tolak dari latar belakang tersebut, maka peneliti memandang perlu adanya penelitian yang mengungkapkan "Pengaruh Kompetensi, Komunikasi Organisasi dan Motivasi terhadap Kinerja Pegawai di Dinas Penanaman Modal dan Perizinan Terpadu Satu Pintu (DPM-PTSP) Provinsi Jambi."

\section{Tujuan Penelitian}

Berdasarkan permasalahan yang ada, adapun tujuan yang dingin dicapai dalam peneltian ini adalah untuk menganalisis pengaruh kompetensi dan komunikasi organisasi terhadap kinerja pegawai di Dinas Penanaman Modal dan Perizinan Terpadu Satu Pintu (DPM-PTSP) Provinsi Jambi baik secara langsung maupun tidak langsung melalui motivasi kerja sebagai variabel intervening. 


\section{TINJAUAN PUSTAKA}

\section{a. Kompetensi}

Secara umum kompetensi lebih menekankan pada perilaku produktif yang harus dimiliki serta diperagakan oleh seseorang dalam melaksanakan suatu pekerjaan agar dapat berprestasi dalam pekerjaannya (Hutapea dan Thoha, 2011). Konsep kompetensi diterapkan dalam berbagai aspek dari Manajemen Sumber Daya Manusia. Awalnya kompetensi dimanfaatkan dalam bidang pelatihan dan pengembangan (Competency Based Training), rekrutmen dan seleksi (Competency Based Recruitmen and Selection) dan sistem remunerasi (Competency Based Payment). Kemudian terakhir kompetensi diintegrasikan ke dalam konsep Competency Based Human Resource Management (Ruky, 2011).

Kompetensi adalah spesifikasi dari pengetahuan dan keterampilan serta penerapan dari pengetahuan dan keterampilan tersebut dalam suatu pekerjaan atau perusahaan atau lintas industri, sesuai dengan standar kinerja yang disyaratkan. Kompetensi adalah rumusan kewenangan berdasarkan pengetahuan, sikap dan ketrampilan yang diakui secara resmi oleh lembaga yang berwenang, yang ditinjau secara berkala. Standar kompetensi adalah bakuan kemampuan minimal. Bakuan tersebut memuat pernyataan yang menguraikan pengetahuan, sikap dan ketrampilan yang harus dimiliki saat bekerja serta penerapannya, sesuai dengan standar yang ditetapkan lapangan pekerjaan (Basori, M.A.N., Prahiawan, W., dan Daenulhay., 2017). Hutapea dan Thoha (2011) mengungkapkan bahwa ada tiga komponen utama pembentukan kompetensi yaitu pengetahuan yang dimiliki seseorang, kemampuan, dan perilaku individu.

\section{b. Komunikasi Organisasi}

Komunikasi organisasi adalah proses menciptakan dan menukar pesan dalam suatu jaringan hubungan yang saling tergantung satu sama lain untuk mengatasi lingkungan yang sering berubah-ubah (Goldhaber, 2006). Katz dan Kahn yang dikutip oleh Arni (2015) dalam bukunya mengatakan bahwa komunikasi organisasi merupakan arus informasi, pertukaran informasi dan pemindahan arti di dalam suatu organisasi. Menurut Katz dan Kahn organisasi adalah sebagai suatu sistem terbuka yang menerima energi dari lingkungannya menjadi produk atau servis dari sistem dan mengeluarkan produk atau servis ini kepada lingkungan.

Komunikasi merupakan aktivitas dasar manusia dan dengan adanya komunikasi yang baik maka suatu organisasi dapat berjalan dengan lancar dan berhasil dan begitu pula sebaliknya apabila kurang atau tidak adanya komunikasi maka organisasi akan macet atau berantakan. Komunikasi organisasi dapat didefinisikan sebagai pertunjukan dan penafsiran pesan diantara unit-unit komunikasi yang merupakan bagian dari suatu organisasi tertentu. Suatu organisasi terdiri dari unit-unit komunikasi dalam hubungan-hubungan hierarkis antara satu dengan lainnya dan berfungsi dalam suatu lingkungan. Komunikasi organisasi terjadi kapanpun juga setidak-tidaknya terdapat satu orang yang menduduki suatu jabatan dalam suatu organisasi yang menafsirkan suatu pertunjukan pesan (Pace dan Faules, 2013). Lebih lanjut Pace dan Faule (2013) mengemukakan bahwa dimensi dan indicator dari komunikasi organisasi terbagi atas empat yaitu komunikasi keatas, komunikasi kebawah, komunikasi horizontal, dan komunikasi lintas saluran.

\section{c. Motivasi Kerja}

Setiap orang dalam melakukan suatu tindakan tertentu pasti didorong oleh adanya motif tertentu. Motivasi biasanya timbul karena adanya kebutuhan yang belum terpenuhinya tujuan yang dicapai, atau karena adanya harapan yang diinginkan. Motivasi 
kerja merupakan kombinasi kekuatan psikologis yang kompleks dalam diri masing-masing orang (Wibowo, 2014). Setiap individu mempunyai motivasi sendiri yang mungkin berbeda.

Menurut McClelland (1987) motivasi merupakan Kondisi jiwa yang mendorong seseorang dalam mencapai prestasinya secara maksimal. Sedangkan menurut Rivai (2014) motivasi merupakan serangkaian sikap dan nilai-nilai yang mempengaruhi individu untuk mencapai hal yang spesifik sesuai dengan tujuan individu. Robbin dan Judge (2015) mendefinisikan motivasi sebagai proses yang menjelaskan mengenai kekuatan, arah, dan ketekunan seseorang dalam upaya untuk mencapai tujuan. Oleh karena motivasi secara umum adalah berkaitan dengan upaya menuju setiap tujuan, kita kan mempersempit fokus menjadi tujuan organisasi terhadap perilaku terkait pekerjaan.

Ada beberapa teori motivasi yang dikemukakan oleh ilmuwan yang menekuni kegiatan pengembangan teori motivasi, diantaranya yaitu teori motivasi berprestasi McClelland. Menurut Mangkunegara (2014) teori motivasi berprestasi McClelland mengemukakan bahwa produktivitas seseorang sangat ditentukan oleh "virus mental" yang ada pada dirinya.Virus mental adalah kondisi jiwa yang mendorong seseorang yang mampu mencapai prestasinya secara maksimal. Virus mental yang dimaksud terdiri dari 3 dorongan kemampuan, yaitu: 1) Need of achievement (n'Ach) (kebutuhan untuk berprestasi); 2) Need of affiliation (n'Aff ) (kebutuhan untuk memperluas pergaulan); dan 3) Need of power (n'Pow) (kebutuhan untuk menguasai sesuatu).

\section{d. Kinerja}

Kinerja pegawai adalah kemampuan yang dicapai dan diinginkan dari perilaku pegawai dalam melaksanakan dan menyelesaikan tugas-tugas pekerjaan yang menjadi tanggung jawab secara individu atau kelompok. Mathis (2020) mengatakan kinerja merupakan banyaknya upaya yang dikeluarkan individu dalam mencurahkan tenaga sejumlah tertentu pada pekerjaan. Sedangkan menurut Simamora (2012) kinerja merupakan tingkat terhadap mana para pegawai dalam melaksanakan tugasnya sesuai dengan tanggung jawab yang diberikan kepadanya. Sedangkan menurut menurut Sutrisno (2014) mendefinisikan kinerja sebagai prestasi yang diperoleh seseorang dalam melakukan tugas.

Menurut Hasibuan (2012), kinerja pegawai dapat dinilai dari: 1) Kuantitas, yaitu jumlah yang harus diselesaikan atau dicapai; 2) Kualitas, yaitu mutu yang harus dihasilkan (baik tidaknya). Pengukuran kualitatif keluaran mencerminkan pengukuran atau tingkat kepuasan yaitu seberapa baik penyelesaiannya; dan 3) Ketepatan waktu, yaitu sesuai tidaknya dengan waktu yang direncanakan.

Sedangkan menurut Mathis (2020) yang menjadi indikator dalam mengukur kinerja atau prestasi pegawai adalah sebagai berikut: 1) Kuantitas kerja, yaitu volume kerja yang dihasilkan dalam kondisi normal; 2) Kualitas kerja, yaitu dapat berupa kerapian ketelitian dan keterkaitan hasil dengan tidak mengabaikan volume pekerjaan; 3) Pemanfaatan waktu, yaitu penggunaan masa kerja yang disesuaikan dengan kebijaksanaan instansi atau lembaga pemerintahan; 4) Kerjasama, yaitu kemampuan menangani hubungan dengan orang lain dalam pekerjaan; dan 5) Kehadiran, yaitu kedisiplinan dalam mematuhi tingkat absensi yang telah disesuaikan dengan kebijakan instansi.

\section{Kerangka Berpikir}

Berdasarkan Kajian teori dan hubungan antar variabel maka model atau Conceptual Framework artikel ini dalam rangka menbagunan hipotesis adalah sebagai berikut: 


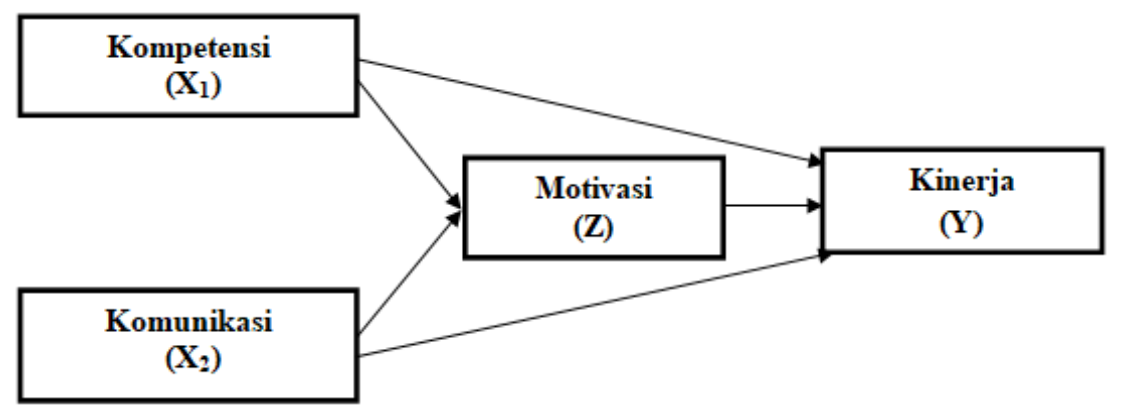

\section{Hipotesis}

Gambar 1. Kerangka Berpikir

Berdasarkan telaah teori dan beberapa asumsi yang telah dikemukakan terdahulu, maka hipotesa penelitian yang diambil adalah sebagai berikut:

H1 : Kompetensi berpengaruh positif dan signifikan terhadap kinerja pegawai.

$\mathrm{H} 2$ : Komunikasi organisasi berpengaruh positif dan signifikan terhadap kinerja pegawai.

H3 : Motivasi berpengaruh positif dan signifikan terhadap kinerja pegawai.

H4 : Kompetensi berpengaruh positif dan signifikan terhadap motivasi kerja pegawai.

H5 : Komunikasi organisasi berpengaruh positif dan signifikan terhadap motivasi kerja pegawai.

H6 : Kompetensi melalui motivasi berpengaruh positif dan signifikan terhadap kinerja pegawai.

H7 : Komunikasi organisasi melalui motivasi berpengaruh positif dan signifikan terhadap kinerja pegawai.

\section{METODE PENELITIAN}

Populasi dalam penelitian ini adalah pegawai pada DPM-PTSP Provinsi Jambi yang berjumlah 147 orang pegawai. Ukuran atau jumlah sampel dalam penelitian ini ditentukan berdasarkan teori yang dikembangkan oleh Slovin dengan margin error sebesar $5 \%$. Berdasarkan rumus penentuan jumlah sampel dari Slovin di atas didapat jumlah sampelnya (n) sebanyak 107,49 di bulatkan menjadi 107.

Teknik analisis data yang penulis gunakan dalam penelitian ini yakni menggunakan Partial Least Square (PLS). Partial Least Square atau disingkat PLS merupakan jenis SEM yang berbasis komponen dengan sifat konstruk formatif. Partial Least Square (PLS) adalah teknik analisis yang powerfull karena dapat diterapkan pada semua skala data, tidak perlu banyak asumsi, dan ukuran sampel sampel pun tidak harus besar. Walaupun PLS digunakan untuk menjelaskan ada tidaknya hubungan antar variabel laten (prediction), PLS juga dapat digunakan untuk mengkonfirmasi teori. Namun sebelum analisis, terlebih dahulu dilakukan uji outer model melalui uji validitas dan reliabilitas. Selanjutnya melakukan uji Inner Model melalui uji R-Square (Coefficient of determination), F-Square dan $\left(f^{2}\right.$ effect size).

\section{HASIL DAN PEMBAHASAN}

\section{Analisis Deskriptif Profil Responden}

Profil responden penelitian dibagi menjadi 4 jenis, yaitu berdasarkan jenis kelamin, usia, tingkat pendidikan, dan masa kerja. Responden berjenis kelamin pria yaitu sebanyak 50,47 persen, dan wanita sebanyak 49,53 persen. Selanjutnya berdasarkan kelompok usia, kelompok atas usia $<25$ tahun sebanyak 6,54 persen, kemudian untuk kelompok usia $26-$ 35 tahun sebanyak 17,76 persen, kelompok usia 36 - 45 tahun sebanyak 32,71 persen, 
untuk kelompok usia 46 - 55 tahun sebanyak 29,91 persen, dan untuk kelompok usia > 55 tahun sebanyak 13,08 persen. Pada karateristik tingkat pendidikan responden, untuk SMA/SMK sebanyak 14,02 persen, Diploma sebanyak 5,61 persen, Strata Satu (S1) sebanyak 55,14 persen, dan untuk Strata Dua (S2) sebanyak 25,23 persen. Pada karateristik berdasarkan masa kerja, untuk < 5 tahun sebanyak 17,76 persen, $6-10$ sebanyak 35,51 persen, 11 - 15 sebanyak 28,97 persen, 16 - 20 tahun sebanyak 11,21 persen, dan untuk $>20$ tahun sebanyak 6,54 persen.

\section{Hasil Deskripsi Jawaban Responden Atas Variabel Penelitian a. Deskripsi Data Variabel Kompetensi $\left(\mathrm{X}_{1}\right)$.}

Dari tiga belas pernyataan yang diajukan untuk variable kompetensi $\left(\mathrm{X}_{1}\right)$ diperoleh skor rata-rata sebesar 401,52. Apabila dilihat pada Kriteria presentase skor responden terhadap skor ideal, variabel kompetensi termasuk pada range 363,8 - 449,3 berada pada kriteria "Baik". Yang menjelaskan bahwasanya kompentensi pegawai pada DPM-PTSP Provinsi Jambi sudah sesuai dengan pekerjaan yang dilaksanakannya.

\section{b. Deskripsi Data Variabel Komunikasi Organisasi $\left(\mathbf{X}_{2}\right)$}

Dari dua belas pernyataan yang diajukan untuk variable komunikasi organisasi $\left(\mathrm{X}_{2}\right)$ diperoleh skor rata-rata sebesar 397,4. Apabila dilihat pada Kriteria presentase skor responden terhadap skor ideal, variabel komunikasi termasuk pada range 363,8 - 449,3 berada pada kriteria "Baik". Yang menjelaskan bahwasanya komunikasi organisasi yang berlangsung pada DPM-PTSP Provinsi Jambi sudah berlangsung dengan baik.

\section{c. Deskripsi Data Variabel Motivasi $(Z)$}

Dari sepuluh pernyataan yang diajukan untuk Variabel motivasi (Z) diperoleh skor rata-rata sebesar 399,33. Apabila dilihat pada Kriteria presentase skor responden terhadap skor ideal, variabel motivasi kerja termasuk pada range 363,8 - 449,3 berada pada kriteria "Tinggi", yang menjelaskan bahwasanya motivasi kerja pegawai pada DPM-PTSP Provinsi Jambi, dapat dikategorikan memiliki motivasi kerja yang tinggi.

\section{d. Deskripsi Data Variabel Kinerja (Y)}

Dari delapan pernyataan untuk variabel kinerja (Y) diperoleh skor rata-rata sebesar 396,4. Apabila dilihat pada kriteria presentase skor responden terhadap skor ideal, variabel kinerja termasuk pada range 363,8 - 449,3 berada pada kriteria "Baik", yang menjelaskan bahwasanya kinerja pegawai pada DPM-PTSP Provinsi Jambi dikategorikan memiliki kinerja yang baik.

\section{Hasil Uji Model Pengukuran Kontruk Reflektif (Outer Model)}

Model pengukuran mempunyai tujuan mewakili hubungan antar kontruk dan variabel indikatornya yang sesuai (umumnya disebut dengan outer model dalam PLSSEM). Model pengukuran menjelaskan bagaimana konstruk diukur dan dapat diandalkan atau valid serta reliabel dengan melihat validitas konvergen, validitas diskriminan, dan reliabilitas kontruk (Hair et al., 2017). Gambar outer model dalam SmartPLS adalah sebagai berikut: 


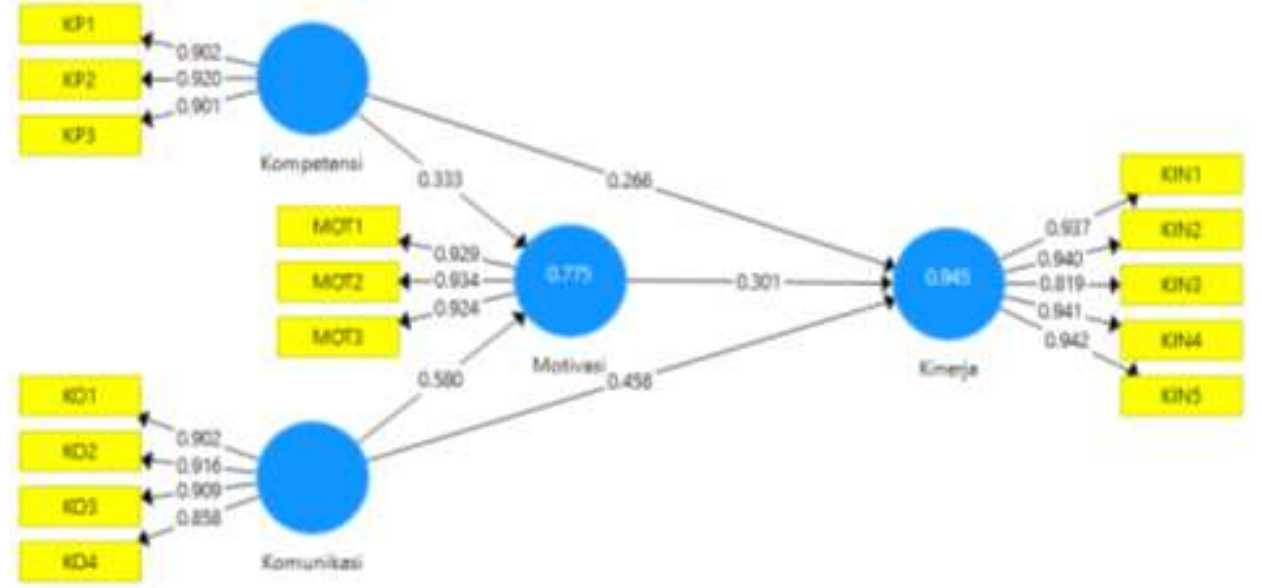

Gambar 2. Outer Model Penelitian pada SmartPLS 3

Uji validitas dengan konstruk reflektif adalah sejauh mana ukuran dari suatu kontruk seharusnya berkorelasi tinggi. Uji validitas konstruk reflektif dengan konstruk reflektif dapat dilihat melalui nilai loading factor untuk tiap indikator kontruk. Rule of thumb yang digunakan yaitu nilai standar loading factor harus 0.7 atau lebih tinggi serta nilai average extracted value (AVE) harus lebih besar dari 0.5. Loading factor yang tinggi menunjukkan bahwa indikator yang terdapat pada konstruk memiliki banyak kesamaan sehingga memiliki makna yang sama pada suatu konstruk (Hair et al., 2017).

Berdasarkan gambar 2 di atas tampak bahwasanya tidak ada indicator di bawah 0,70, dan semua outer loading sangat jauh dari 0,4 , dan di atas nilai AVE, oleh karenanya maka dapat disimpulkan bahwa semua indikator telah memenuhi rule of thumb. Sehingga tidak perlu dilakukan eliminasi indicator, dan melakukan estimasi ulang. Selain itu, berdasarkan hasil nilai composite reliability yang dihasilkan semua konstruk lebih dari 0,7 dengan nilai minimum yaitu 0,934 yang ditunjukkan oleh variabel kompetensi. Maka dari itu, dapat disimpulkan bahwa semua konstruk dalam penelitian ini adalah reliabel atau memenuhi uji reliabilitas.

\section{Hasil Uji Model Struktural (Inner Model)}

Ketika model pengukuran (outer model) telah menyatakan hasil yang baik, langkah selanjutnya dalam mengevaluasi hasil PLS-SEM adalah dengan menilai model struktural (inner model). Model struktural dianalisis yaitu sebagai upaya untuk menemukan bukti bukti yang mendukung model teoritis (hubungan teoritis antara konstruk eksogen dan konstruk endogen) (Ghozali, 2015).

\section{a. Nilai R-Square (Coefficient of determination)}

Nilai R-square digunakan untuk menunjukkan sejauh mana konstruk eksogen menjelaskan kontruk endogen. Untuk mengevaluasi model struktural yaitu dengan nilai $R$ square yang menunjukkan kekuatan prediktif dari model. Rule of thumb yang digunakan yaitu $0.75,0.50$, dan 0.25 menunjukkan bahwa model kuat, moderat, dan lemah. (Hair et al, 2017). Hasil nilai R-square dapat dilihat pada tabel dibawah ini sebagai berikut:

Tabel 1. Nilai $R$-Square

\begin{tabular}{|l|r|r|}
\hline \multicolumn{1}{|c|}{ Variabel } & \multicolumn{1}{c|}{ R Square } & R Square Adjusted \\
\hline Motivasi (Z) & 0,775 & 0,771 \\
\hline Kinerja (Y) & 0,945 & 0,944 \\
\hline
\end{tabular}

Sumber: Output SmartPLS 3, 2021. 
Berdasarkan hasil pengolahan data pada tabel di atas, menunjukkan bahwa variabel motivasi mempunyai nilai R-square sebesar 0,775 yang berarti bahwa variabel motivasi dapat dijelaskan oleh konstruk kompetensi dan komunikasi organisasi dengan persentase sebesar 77,2\%. Sedangkan variabel kinerja mempunyai nilai R-square sebesar 0,945 yang berarti bahwa variabel kinerja dapat dijelaskan oleh konstruk kompetensi, komunikasi organisasi dan motivasi kerja dengan persentase sebesar 94,5\%. Maka, dapat disimpulkan bahwa hasil uji model struktural (inner model) dari variabel motivasi kerja dan variabel kinerja pegawai termasuk kategori model yang "kuat".

b. Nilai F-Square ( $f^{2}$ Effect Size $)$

F-square dihitung untuk mengukur pentingnya perubahan nilai R-square ketika konstruk tertentu dihilangkan dari model untuk mengevaluasi apakah konstruk yang dihilangkan memiliki dampak substantif pada kosntruk endogen. Rule of thumb untuk menilai nilai f-square adalah $0.02,0.15$, dan 0.35 yang menunjukkan bahwa nilai efek kecil, sedang dan besar, serta ukuran efek dengan nilai kurang dari 0.02 menunjukkan bahwa variabel tidak mempunyai efek (Hair et al, 2017). Hasil nilai F-square dapat dilihat pada tabel dibawah ini sebagai berikut :

Tabel 2. Nilai F-Square

\begin{tabular}{|c|c|c|c|c|}
\hline Variabel & $\begin{array}{c}\text { Kompetensi } \\
\text { (X1) }\end{array}$ & $\begin{array}{c}\text { Komunikasi } \\
\text { (X2) }\end{array}$ & Motivasi (Z) & $\operatorname{Kinerja}(\mathbf{Y})$ \\
\hline Kompetensi $\left(\mathbf{X}_{1}\right)$ & & & 0,141 & 0,321 \\
\hline Komunikasi $\left(\mathbf{X}_{2}\right)$ & & & 0,427 & 0,762 \\
\hline Motivasi (Z) & & & & 0,371 \\
\hline Kinerja (Y) & & & & \\
\hline
\end{tabular}

Sumber: Output SmartPLS 3, 2021.

Berdasarkan hasil pengolahan data pada tabel diatas, maka dapat dilihat bahwa terdapat 1 variabel yang memiliki kontribusi terbesar dalam terhadap nilai R-square pada model penelitian yaitu nilai f-square variabel kompetensi dan komunikasi organisasi terhadap motivasi kerja masing-masing yaitu sebesar 0,141 atau $14,1 \%$ (kecil), dan 0,427 atau $42,7 \%$ (besar). Kemudian untuk variable kompetensi dan komunikasi organisasi terhadap kinerja masing-masing yaitu sebesar 0,321 atau 32,1\% (Sedang) dan 0,762 atau $76,2 \%$ (besar). Berikutnya variabel motivasi kerja terhadap kinerja yaitu sebesar 0,371 atau $37,1 \%$ (Kecil).

\section{Hasil Pengujian Hipotesis}

Pengujian selanjutnya yaitu melihat signifikansi yang mewakili hubungan yang di hipotesiskan di antara konstruk atau melihat pengaruh antar variabel pada path coefficients menggunakan prosedur bootsrapping. Selanjutnya yaitu output bootsrapping untuk melihat besaran nilai T-statistik. 


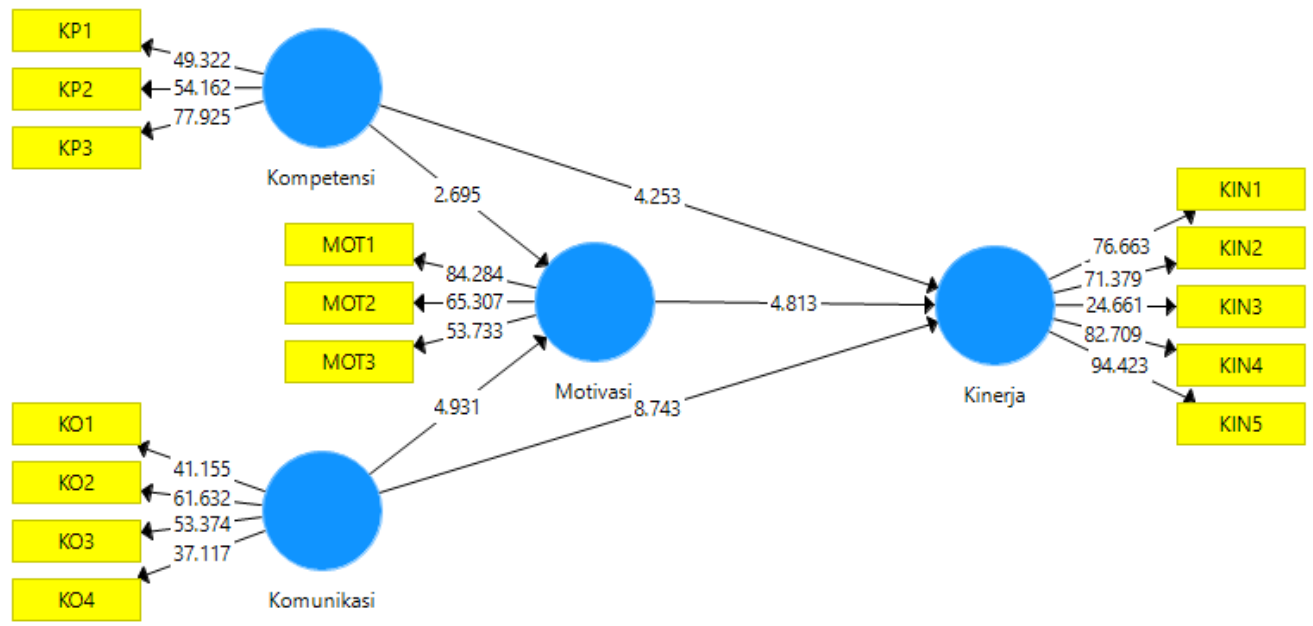

Gambar 3. Model Hubungan Konstruk Penelitian Dengan Metode Bootstrapping

\section{Pengaruh Langsung (Direct Effect)}

Analisis pengaruh langsung berguna untuk menguji hipotesis pengaruh langsung suatu variabel yang mempengaruhi (eksogen) terhadap variabel yang dipengaruhi (endogen). Hasil pengolahan data disajikan pada tabel di bawah ini sebagai berikut:

Tabel 3. Hasil Path Coefficients

\begin{tabular}{|l|c|c|c|c|}
\hline \multicolumn{1}{|c|}{ Hipotesis } & $\begin{array}{c}\text { Path } \\
\text { Coefficient }\end{array}$ & T-Statistics & P Value & Keterangan \\
\hline $\mathrm{H} 1: \mathrm{X} 1->\mathrm{Z}$ & 0,266 & 4,253 & 0,000 & Diterima \\
\hline $\mathrm{H} 2: \mathrm{X} 2->\mathrm{Z}$ & 0,458 & 8,743 & 0,000 & Diterima \\
\hline $\mathrm{H} 3: \mathrm{Y}->\mathrm{Z}$ & 0,301 & 4,813 & 0,000 & Diterima \\
\hline $\mathrm{H} 4: \mathrm{X} 1->\mathrm{Y}$ & 0,333 & 2,695 & 0,007 & Diterima \\
\hline $\mathrm{H} 5: \mathrm{X} 2->\mathrm{Y}$ & 0,580 & 4,931 & 0,000 & Diterima \\
\hline $\mathrm{H} 6: \mathrm{X} 1->\mathrm{Y}->\mathrm{Z}$ & 0,100 & 2,190 & 0,029 & Diterima \\
\hline $\mathrm{H} 7: \mathrm{X} 2->\mathrm{Y}->\mathrm{Z}$ & 0,174 & 3,515 & 0,000 & Diterima \\
\hline
\end{tabular}

Sumber: Output SmartPLS 3, 2020.

Hasil uji path coefficients pada tabel diatas dapat diintreprestasikan yaitu dengan melihat nilai original sampel untuk mengetahui hubungan antar variabel. Sedangkan untuk melihat tingkat signifikansi pengaruh hubungan antar variabel yaitu dengan melihat $\mathrm{T}$ Statistics. Pengujian hipotesis dalam penelitian ini menggunakan nilai signifikansi (significance level) sebesar 5\% (two tailed) dan tingkat keyakinan (confidence level) sebesar 95\% sehingga t-tabel adalah 1,96, apabila nilai $\mathrm{T}$-statistik > t-tabel maka hasilnya signifikan (Ghozali, 2015).

Berdasarkan data hasil pengujian pada tabel diatas, terdapat 7 hipotesis dan semuanya diterima dengan nilai t-statistik $>1,983$. Berikut ini hasil dari pengujian hipotesis dari tiap konstruk yaitu sebagai berikut:

1. Kompetensi terhadap kinerja memiliki nilai koefisien jalur sebesar 0,266 dengan nilai tstatistik sebesar 4,253 dan P Value sebesar 0,000. Dikarenakan nilai P Valuenya $<5 \%$ $(0,000<0,05)$ maka dapat disimpulkan bahwa variabel kompetensi berpengaruh signifikan terhadap kinerja pegawai. Dengan demikian maka dapat disimpulkan bahwa hipotesis $1(\mathrm{H} 1)$ diterima. Hasil penelitian ini menunjukan hasil yang sama dengan 
penelitian yang dilakukan oleh Ataunur, I., dan Ariyanto, E (2015), Kartika, L.N., dan Sugiarto, A (2014), Purwanto, B.H., dan Soliha, E (2017), dan Yuliana (2017) yang mengemukakan bahwa kompetensi berpengaruh positif dan signifikan terhadap kinerja pegawai. Hal ini terjadi karena dengan kompetensi yang dimiliki pegawai bersangkutan semakin mampu untuk melaksanakan tugas-tugas yang dibebankan kepadanya (Rande, D., 2016).

2. Komunikasi organisasi terhadap kinerja pegawai memiliki nilai koefisien jalur sebesar 0,458 dengan nilai t-statistik sebesar 8,743 dan P Value sebesar 0,000. Dikarenakan nilai $\mathrm{P}$ Valuenya $<5 \%(0,000<0,05)$ maka dapat disimpulkan bahwa variabel komunikasi organisasi berpengaruh signifikan terhadap kinerja pegawai. Dengan demikian maka dapat disimpulkan bahwa hipotesis $2(\mathrm{H} 2)$ diterima. Hasil penelitian ini sejalan dengan penelitian yang dilakukan oleh Alam, S (2014), Anshari, H., Masjaya, H., dan Amin, H.J (2014), Ardiansyah, D.O (2016), Azwina, D., dan Yusuf, S (2020), Purwanto, S.B (2013), dan Vesmagita, S (2015) yang menyatakan secara signifikan dan positif kinerja dipengaruhi oleh komunikasi. Ini dapat diartikan bahwa semakin baik dan efektif komunikasi yang berlangsung dalam organisasi, maka akan menciptakan iklim kerja kantor yang sehat dan terbuka. Hal ini sangat penting guna memusatkan kreativitas dan dedikasi para pegawai kantor. Oleh karena itu dalam sebuah organisasi dibutuhkan komunikasi yang efektif.

3. Motivasi kerja terhadap kinerja pegawai memiliki nilai koefisien jalur sebesar 0,301 dengan nilai t-statistik sebesar 4,813 dan P Value sebesar 0,000. Dikarenakan nilai $\mathrm{P}$ Valuenya $<5 \%(0,000<0,05)$ maka dapat disimpulkan bahwa variabel motivasi kerja berpengaruh signifikan terhadap kinerja pegawai. Dengan demikian maka dapat disimpulkan bahwa hipotesis 3 (H3) diterima. Hasil penelitian ini sejalan dengan penelitian yang dilakukan oleh Basori, A.N.B., Prahiawan, W., dan Daenulhay (2017), Dhermawan, A.A.N.B., Sudibya, I.G.A., dan Utama, I.W.M (2012), Maizar, J (2017), Purwanto, S.B (2013), dan Septiyani dan Sanny, L (2013) yang menyatakan secara signifikan dan positif kinerja dipengaruhi oleh motivasi kerja. Ini dapat diartikan bahwa dengan adanya motivasi yang tinggi ini akan berpengaruh terhadap kinerja yang tinggi pula. Motivasi adalah suatu faktor yang mendorong seseorang untuk melakukan suatu aktivitas tertentu, oleh karena itu motivasi sering kali diartikan pula sebagai faktor pendorong perilaku seseorang (Sutrisno, 2014). Motivasi merupakan dorongan dari dalam diri pegawai untuk mencapai suatu tujuan. Seorang pegawai akan melakukan tugasnya dengan baik jika ada dorongan dari dalam dirinya.

4. Kompetensi pegawai terhadap motivasi kerja memiliki nilai koefisien jalur sebesar 0,333 dengan nilai t-statistik sebesar 2,695 dan P Value sebesar 0,007. Dikarenakan nilai $\mathrm{P}$ Valuenya $<5 \%(0,007<0,05)$ maka dapat disimpulkan bahwa variabel kompetensi berpengaruh signifikan terhadap motivasi kerja. Dengan demikian maka dapat disimpulkan bahwa hipotesis 4 (H4) diterima. Kompetensi merupakan pola pengetahuan, keterampilan, kemampuan, perilaku dan karakteristik terukur lainnya yang dibutuhkan oleh seseorang untuk melakukan peran atau fungsi pekerjaan (Yang et al dalam Roni, K.A., Moein, A., \& Effendi, N.I., 2018). Pentingnya kompetensi yang dimiliki oleh seorang karyawan dalam melakukan sebuah pekerjaan, karena dengan memiliki kompetensi akan mampu mendorong dan memotivasi pegawai untuk melaksanakan pekerjaannya dengan baik.

5. Komunikasi organisasi terhadap motivasi kerja memiliki nilai koefisien jalur sebesar 0,580 dengan nilai t-statistik sebesar 4,931 dan P Value sebesar 0,000. Dikarenakan nilai $\mathrm{P}$ Valuenya $<5 \%(0,000<0,05)$ maka dapat disimpulkan bahwa variabel 
komunikasi organisasi berpengaruh signifikan terhadap motivasi kerja pegawai. Dengan demikian maka dapat disimpulkan bahwa hipotesis 5 (H5) diterima. Aliran komunikasi yang lancar dan jelas serta sampai sesuai dengan kebutuhan berpengaruh terhadap motivasi kerja karyawan. Kelancaran aliran informasi di dalam suatu perusahaan berdampak kepada penerimaan yang positif dari bawahan berupa pemahaman perintah, dan tanggung jawab kerja (Haryati, E., dan Kesumadewi, L., 2015). Selain itu Prakoso, T., dan Putri, Y.R (2017) dalam penelitiannya juga mengungkapkan jika komunikasi organisasi memiliki pengaruh terhadap motivasi kerja karyawan.

6. Kompetensi terhadap kinerja pegawai melalui motivasi kerja memiliki nilai koefisien jalur sebesar 0,100 dengan nilai t-statistik sebesar 2,190 dan P Value sebesar 0,029. Dikarenakan nilai P Valuenya $<5 \%(0,029<0,05)$ maka dapat disimpulkan bahwa variabel kompetensi melalui motivasi berpengaruh signifikan terhadap kinerja pegawai. Dengan demikian maka dapat disimpulkan bahwa hipotesis 6 (H6) diterima. Hasil ini menjelaskan bahwa jika pegawai memiliki kompetensi yang baik dalam melaksanakan tugas pokok dan fungsinya, serta di dukung pula dengan adanya dorongan (motivasi) dari dalam diri maupun dari luar (atasan) maka hal ini akan semakin meningkatkan kinerja pegawai dalam melaksanakan tugas pokok dan fungsinya.

7. Komunikasi organisasi terhadap kinerja pegawai melalui motivasi kerja memiliki nilai koefisien jalur sebesar 0,174 dengan nilai t-statistik sebesar 3,515 dan P Value sebesar 0,000 . Dikarenakan nilai $\mathrm{P}$ Valuenya $<5 \%(0,000<0,05)$ maka dapat disimpulkan bahwa variabel komunikasi organisasi melalui motivasi berpengaruh signifikan terhadap kinerja pegawai. Dengan demikian maka dapat disimpulkan bahwa hipotesis 7 (H7) diterima. Hasil ini menjelaskan bahwa jika komunikasi yang ada dalam organisasi dapat berlangsung secara efektif, maka hal ini akan lebih memotivasi pegawai untuk dapat bekerja lebih baik. Komunikasi sangat esensial sekali bagi kehidupan organisasi khususnya untuk pegawai dan atasan dalam mencapai tujuan, karena komunikasi sebuah organisasi mempengaruhi cara hidup seseorang: kepada siapa mereka berbicara, siapa yang mereka sukai, bagaimana perasaan mereka, apa yang ingin mereka capai, dan bagaimana cara mereka menyesuaikan diri dengan organisasi (Zelko dan Dance dalam Arni, 2015). Jika komunikasi yang berlangsung dalam organisasi baik itu komunikasi antara atasan dengan bawahan, maupun antara bawahan dengan sesama bawahan dapat berlangsung secara efektif, maka hal ini akan dapat lebih meningkatkan motivasi kerja pegawai untuk memberikan hasil kinerja yang baik untuk pencapaian tujuan organisasi.

\section{SIMPULAN DAN SARAN}

\section{Simpulan}

1. Berdasarkan hasil penelitian dan pembahasan dalam penelitian ini, maka dapat disimpulkan bahwa kompetensi dan komunikasi organisasi berpengaruh positif dan signifikan terhadap kinerja pegawai, baik secara langsung maupun tidak langsung melalui motivasi kerja.

2. Jika DPM-PTSP Provinsi Jambi memiliki pegawai dengan kompetensi yang baik, serta didukung dengan adanya komunikasi organisasi yang berlansung secara efektif, maka hal ini akan meningkatkan motivasi pegawai dalam bekerja. Jika pegawai telah memiliki motivasi yang tinggi dalam bekerja, maka hal ini secara tidak langsung akan memberikan dampak pada hasil hasil kerja pegawai yang optimal. 


\section{Saran}

Kedepan di harapkan pegawai dapat memperbaiki sikap yang baik dalam bekerja, dengan lebih disiplin dalam melaksanakan tugas yang diberikan agar pekerjaan yang dilaksanakan dapat terlaksana dengan baik dan tepat waktu.

Kedepan diharapkan pimpinan harus lebih terbuka bagi pegawainya, agar pegawai dapat lebih mudah dalam melakukan hubungan komunikasi dengan atasannya, agar semua kegiatan kerja dapat terlaksana dengan baik.

Diharapkan kedepan pimpinan DPM-PTSP Provinsi Jambi dapat memberikan dorongan pada bawahannya untuk dapat meningkatkan kualitas kerjanya, untuk lebih rapih dan teliti lagi dalam bekerja, agar hasil kerja yang diberikanpun dapat leibh maksimal.

Kedepan diharapkan pada instansi terkait dapat memberikan teguran dan sanksi kepada pegawai yang sering menunda-nunda pekerjaannya, agar menjadi contoh pegawai lainnya untuk senantiasa dapat bekerja dengan baik, agar kinerja organisasipun dapat berjalan secara optimal.

Penelitian ini perlu di tindak lanjuti lagi untuk melihat faktor apa saja yang dapat mempengaruhi motivasi kerja dan kinerja pegawai.

\section{DAFTAR PUSTAKA}

Alam, S. (2014). Pengaruh Komunikasi, Motivasi, dan Disiplin Kerja Terhadap Kinerja Pegawai Lembaga Penjaminan Mutu Pendidikan. e-Jurnal Katalogis, Volume 2, Nomor 1.

Anshari, H., Masjaya, H., dan Amin, H.J. (2014). Pengaruh Komunikasi Organisasi dan Budaya Organisasi Terhadap Kinerja Pegawai Bagian Sosial Sekretariat Daerah Kabupaten Kutai Timur. Jurnal Administrative Reform, Vol. 2, No. 3.

Ardiansyah, D.O. (2016). Pengaruh Komunikasi Terhadap Kineraj Karyawan Dengan Dimediasi Oleh Kepuasan Kerja. Jurnal Bisnis dan Manajemen, Vol. 3, No. 1.

Arni, M. (2015). Komunikasi Organisasi. Edisi 3, Cet. 12. Jakarta: Bumi Aksara.

Ataunur, I., dan Ariyanto, E. (2015). Pengaruh Kompeten dan Pelatihan Terhadap Kinerja Karyawan PT. Adaro Energy Tbk. Telaah Bisnis, Volume 16, Nomor 2.

Azwina, D., dan Yusuf, S. (2020). Pengaruh Komunikasi Organisasi Terhadap Kinerja Karyawan pada PT. Gapa Citramandiri, Radio Dalam - Jakarta Selatan. Jurnal Disrupsi Bisnis, Vol. 3, No. 1.

Basori, M.A.N., Prahiawan, W., dan Daenulhay. (2017). Pengaruh Kompetensi Karyawan dan Lingkungan Kerja Terhadap Kinerja Karyawan Melalui Motivasi Kerja Sebagai Variabel Intervening (Studi pada PT. Krakatau Bandar Samudra). Jurnal Riset Bisnis dan Manajemen Tirtayasa (JRBMT), Vol. 1 (2).

Dessler, G. (2009). Manajemen Sumber Daya Manusia. Jakarta: Salemba Empat.

Dhermawan, A.A.N.B., Sudibya, I.G.A., dan Utama, I.W.M. (2012). Pengaruh Motivasi, Lingkungan Kerja, Kompetensi, dan Kompensasi Terhadap Kepuasan Kerja dan Kinerja pegawai di Lingkungan Kantor Dinas Pekerjaan Umum Provinsi Bali. Jurnal Manajemen, Strategi Bisnis, dan Kewirausahaan, Vol. 6, No. 2.

Ghozali, I. (2015). Structural Equation Modeling: Teori, Konsep dan Aplikasi dengan Program Lisrel 9.10, Edisi 4. Semarang: Badan Penerbit UNDIP.

Goldhaber, Gerald M. (2006). Organizational Communication. Wm. C. Brown Publisher, Dubuque.

Hair, J.F., Tomas, G.M.H., Ringle, Christian M., dan Marko Sarstedt. (2017). Primer Partial Least Squares Structural Equation Modeling. Los Angeles: SAGE Publication.Ltd. 
Hasibuan, M. S. P. (2012). Manajemen Sumber Daya Manusia, edisi Revisi. Jakarta: Bumi Aksara.

Hutapea, P., dan Thoha, N. (2011). Kompetensi Plus. Jakarta: PT Gramedia.

Kartika, L.N., dan Sugiarto, A. (2014). Pengaruh Tingkat Kompetensi Terhadap Kinerja Pegawai Administrasi Perkantoran. Jurnal Ekonomi dan Bisnis, Volume XVII, No. 1.

Maizar, J. (2017). Pengaruh Motivasi, Kompetensi Kerja dan Kompensasi Terhadap Kinerja Karyawan Pada PT. Perkebunan Nusantara VI (Persero) Pasaman Barat. Jurnal EKOBISTEK Fakultas Ekonomi, Vol. 6, No. 2.

Mangkunegara, A. P. (2014). Manajemen Sumber Daya Manusia Perusahaan, Cetakan ke-2. Bandung: PT. Remaja Rosdakarya Offset.

Mathis, R. L. (2020). Manajemen Sumber Daya Manusia, Jilid 3, Jakarta: Salemba Empat.

Pace R. Wayne dan Faules Don F. (2013). Komunikasi Organisasi: Strategi Meningkatkan Kinerja Perusahaan. Bandung: PT. Remaja Rosdakarya.

Prakoso, T., dan Putri, Y.R. (2017). Pengaruh Komunikasi Organisasi Terhadap Motivasi Kerja Karyawan Kantor Wilayah Kementerian Hukum dan HAM Jawa Barat. $e$ Proceeding of Management, Vol. 4, No. 2.

Purwanto, B.H., dan Soliha, E. (2017). Pengaruh Karakteristik Pekerjaan dan Kompetensi Terhadap Kinerja Melalui Komitmen Organisasional. Jurnal Manajemen, Volume XXI, No. 02 .

Purwanto, S.B. (2013). Pengaruh Komunikasi, Motivasi dan Kepuasan Kerja Terhadap Kinerja Karyawan (Studi pada Proyek Pondasi Tower di Timor Leste PT Cahaya Inspirasi Indonesia). Jurnal Aplikasi Manajemen, Volume 11, Nomor 1.

Rande, D. (2016). Pengaruh Kompetensi Terhadap Kinerja Pegawai pada Dinas Perhubungan, Komunikasi dan Infomatika Kabupaten Mamuju Utara. e Jurnal Katalogis, Volume 4, Nomor 2.

Rivai, V. (2014). Manajemen Sumber Daya Manusia untuk Perusahaan, dari Teori ke Praktik. Jakarta: PT. Raja Grafindo Persada.

Robbins, S.P \& Judge, T.A. (2015). Perilaku Organisasi. Jakarta: PT. Salemba Empat.

Ruky, A. S. (2011). Sistem Manajemen Kinerja. Jakarta : PT Bumi Aksara.

Sari, I., dan Nurdin. (2016). Pengaruh Komunikasi Internal Terhadap Motivasi Kerja Pegawai. Jurnal Administrasi Pendidikan, Vol. XXIII, No. 1.

Septiyani dan Sanny, L. (2013). Analisis Pengaruh Kompetensi Individu dan Motivasi Terhadap Kinerja Karyawan PT. PT. Beta Setia Mega. BINUS BUSINESS REVIEW, Vol. 4, No. 1.

Simamora, H. (2012). Manajemen Sumber Daya Manusia, edisi keempat, cetakan pertama. Yogyakarta: YKPN.

Sutrisno, E. (2014). Manajemen Sumber Daya Manusia. Jakarta: Prenada Media Group.

Vesmagita, S. (2015). Pengaruh Komunikasi Organsasi dan Lingkungan Kerja Terhadap Kinerja Karyawan Tetap pada PT. Mah Sing Indonesia. Jurnal Ilmiah Manajemen dan Bisnis, Volume 1, Nomor 1.

Wibowo. (2014) Perilaku Dalam Organisasi. Jakarta: RajaGrafindo Persada.

Yuliana. (2017). Pengaruh Kompetensi dan Motivasi Kerja Terhadap Kinerja karyawan Perusahaan pada PT Haluan Star Logistic. Jurnal Ilmiah Manajemen Bisnis, Vol. 17, No. 2. 